\title{
SUBJEKTIVITAS PEREMPUAN: PEKERJA SEKS DALAM TIGA KARYA UTUY TATANG SONTANI
}

\author{
${ }^{1}$ Ritma Fakhrunnisa, ${ }^{2}$ Lina Meilinawati Rahayu, ${ }^{3}$ Muhamad Adji \\ ${ }^{123}$ Fakultas Ilmu Budaya, Universitas Padjadjaran \\ 1ritma13001@mail.unpad.ac.id
}

\begin{abstract}
Abstrak
Penelitian ini mengambil topik subjektivitas perempuan pekerja seks dalam tiga karya Utuy Tatang Sontani: Selamat Jalan Anak Kufur, "Menuju Kamar Durhaka", dan "Doger". Tiga pekerja seks tersebut ditampilkan melalui tokoh Titi, Aku, dan Selendang Merah. Dengan menggunakan metode kritik feminis yang berfokus pada isu tubuh dan ruang perempuan, pembahasan dibagi menjadi dua bagian yang berkaitan dengan tubuh, ruang, dan subjektivitas pekerja seks. Berdasarkan hasil analisis dapat dimaknai bahwa: (1) tubuh dan ruang pekerja seks ditampilkan sebagai aset ambivalen dalam posisinya sebagai subjek dan objek; (2) posisi subjek-objek yang bahagia berkaitan erat dengan perspektif yang digunakan tokoh dalam memandang pekerja seks. Oleh sebab itu, dapat diargumentasikan bahwa Utuy memosisikan tiga tokoh perempuannya dalam posisi subjek dan objek yang tidak ajek.
\end{abstract}

Kata Kunci: perempuan, tubuh, ruang, subjektivitas

\begin{abstract}
This research talks about the subjectivity of women sex workers in Utuy Tatang Sontani's works titled Selamat Jalan Anak Kufur, "Menuju Kamar Durhaka", and "Doger." Women sex worker are portrayed through characters named Titi, Aku, and Selendang Merah. By using a feminist literary criticism method that focuses on women's body and space, the discussion has been divided into two sections related to body, space, and subjectivity of the sex workers. Body and space are the crucial aspects for the characters in Utuy's works when achieving their status as a subject. Based on the results of the analysis it can be interpreted that: (1) the bodies and spaces of the sex workers are depicted as an ambivalent asset in their position both as subject and object; (2) the position of happy subject-object status of the sex workers is closely related to the perspective used by the character in looking at sex workers. Therefore, it can be argued that Utuy positioned the three women characters in the position of subjects and objects that were not fixed.
\end{abstract}

Keywords: women, body, space, subjectivity

\section{PENDAHULUAN}

Tulisan ini memuat pembahasan mengenai tiga tokoh perempuan yang menjadi pekerja seks dalam tiga karya Utuy Tatang Sontani (Utuy). Ketiga karya tersebut adalah Selamat Jalan Anak Kufur (1956), "Menuju Kamar Durhaka” (1951), dan "Doger" (1951) - "Menuju Kamar Durhaka" dan "Doger" diterbitkan dalam kumpulan cerpen Orang-Orang Sial pada 1951 dan diterbitkan ulang dengan judul Menuju Kamar Durhaka pada 2002. Terdapat kecenderungan pada tiga tokoh perempuan dalam kerangka subjektivitas yang ditampilkan melalui tubuh dan 
ruangnya. Ketiga tokoh tersebut ditampilkan Utuy dengan cara yang tidak paten. Alih-alih dihakimi, ketiga tokoh ditampilkan secara dilematis. Posisi subjek-objek mereka dalam prostitusi berubah berdasarkan perspektif yang ditampilkan dalam dialog antartokoh.

Utuy mulai dikenal melalui dramanya yang berjudul Awal dan Mira. Melalui drama tersebut, Utuy dianugerahi Hadiah BMKN 1952. Toer sebagaimana dikutip oleh Supartono (2001: 133) menjuluki Utuy sebagai raksasa dramaturg Indonesia pada masanya. Meskipun ia lebih dikenal dalam dunia penulisan naskah drama, ia juga menulis prosa. Bahkan, drama-dramanya-dimulai dari Awal dan Miraditulis sebagaimana bentuk prosa. Hal tersebut yang membedakan drama Utuy dengan drama pada umumnya. Berdasarkan pernyataan Utuy dalam pengantar yang ditulis oleh Rosidi (2014b: 6), penulisan dengan cara tersebut bertujuan untuk memudahkan pembaca yang membaca karyanya. Perubahan bentuk tersebut sekilas membuat drama dan prosanya tampak sama, tetapi terdapat perbedaan porsi narasi di luar dialog dalam keduanya: prosa memiliki lebih banyak narasi di luar dialog dibandingkan drama. Namun, karena ia lebih banyak menulis drama, ia pun lebih dikenal sebagai penulis naskah drama.

Kecuali menampilkan perubahan bentuk pada drama, Utuy tidak memberikan banyak perubahan tema pada setiap tulisannya. Ia cenderung mengulang tema yang sama melalui tokoh dan cerita yang berbeda. Hal itu bisa disebut sebagai konsistensinya terhadap ideologi yang diyakininya, tetapi juga sebuah stagnasi dalam kepenulisannya. Karya-karyanya cenderung humanis, banyak membahas masalah kemanusiaan di kalangan masyarakat kelas bawah, seperti kehidupan para tokoh dalam tiga objek penelitian ini. Menurut Aveling (1979: 25), melalui karyanya Utuy memperlihatkan kegagalan hubungan antarmanusia karena faktor ekonomi dan politik. Karena itu pula, dalam kedua bukunya tentang Utuy, Aveling (1969 \& 1979) lebih menekankan analisisnya pada aspek sosial dalam karya. Namun, hanya Saptawuryandari (2016) yang melihat pentingnya penggambaran perempuan dalam karya-karya Utuy. Masalah itu juga yang menurut saya penting untuk dibahas.

Utuy bisa dibilang memiliki kedekatan secara emosional dengan perempuan. Supartono (2001: 154) terutama mengaitkan Onih, perempuan pekerja seks yang dicintai Utuy, sebagai inspirasi utama beberapa tokoh dalam karya Utuy. Namun, kedekatan Utuy dengan tokoh perempuannya sering terlesapkan oleh masalah, yang bagi Aveling (1979: 5), lebih banyak bersinggungan dengan perubahan sosial. Rosidi (2018: 123), teman setia yang menjalin hubungan benci tapi cinta dengan Utuy, menyebutkan bahwa karya-karya Utuy setelah masuk Lembaga Kebudayaan Rakyat (Lekra) tidak lagi bermutu. Penurunan mutu tersebut juga terlihat dari perubahan Utuy memosisikan perempuan dalam karyanya. Takada lagi kedekatan dan keakraban pada tokoh perempuan yang kerap terlihat dalam karya-karya sebelum ia masuk Lekra.

Pada awal kepenulisannya, terutama sebelum masuk Lekra, perempuan dimunculkan sebagai tokoh utama yang memiliki porsi bersuara yang seimbang dengan laki-laki, misalnya dalam Awal dan Mira (1952) dan Bunga Rumah Makan (1948). Perempuan pekerja seks pun tidak diposisikan sebagai instrumen, tetapi justru sebaliknya. Melalui hubungan saling memberi dan menerima, perempuan tidak dipandang sebagai hiburan, tetapi sebagai penghibur. Tokoh Selendang Merah dalam "Doger" adalah contoh pekerja seks yang memberikan hiburan 
melalui kesenian. Pada masa sulit revolusi, kesenian tradisional tersebut menjadi pertunjukan komersial yang berkaitan erat dengan prostitusi. Nopianti (2014: 82) menyatakan bahwa hal tersebut berkaitan dengan dinamika sosial. Ini juga berkaitan dengan argumen Beauvoir (2011: 685), bahwa prostitusi mengalami peningkatan pada masa perang dan krisis pascaperang. Dari argumen tersebut dapat diketahui bahwa prostitusi adalah hubungan saling membutuhkan yang berkaitan dengan kebutuhan. Posisi subjek-objek pun menjadi permasalahan perspektif.

Mengutip dari Estes (2008: 355), seorang pekerja seks berada dalam posisi subjektif yang problematis. Masalah subjek-objek dalam prostitusi tidak sesederhana memosisikan pekerjanya berdasarkan situasi dan kondisi. Karena ada dua subjek dalam prostitusi: pekerja seks dan pelanggan, penting untuk mengetahui perspektif yang digunakan. Utuy dalam ketiga karyanya secara dominan menampilkan prostitusi dari sudut pandang perempuan pekerja seks. Terutama dalam "Menuju Kamar Durhaka" dan Selamat Jalan Anak Kufur, perempuan dijadikan tokoh utama yang menceritakan pengalamannya. Setiap dialog selalu menghadirkan Titi, sedangkan pelanggannya bergantian datang ke tempatnya dan memulai percakapan, misalnya dalam dialog Titi dengan muncikarinya, "Mau seenaknya saja menganggap tempat saya sebagai tempatnya" (Sontani, 2014a: 12). Kutipan tersebut menunjukkan bahwa perspektif dominan ditampilkan melalui pekerja seks, terutama karena setiap percakapan disaksikan oleh Titi. Titi bersikap "dingin" pada pelanggan yang tidak mau langsung membayarnya. Hal itu juga menunjukkan kuasanya atas pelanggan ketika berada di tempat kerjanya.

Norberg, sebagaimana dikutip oleh Tallent (2005: 215) berargumen bahwa kebebasan pekerja seks membuat mereka kekurangan subjektivitas mereka sebagai perempuan. Hal itu karena pekerja seks bersifat individualistik. Mereka cenderung mementingkan dirinya sendiri. Pekerja seks bukan hanya menjadi "musuh" para istri, tetapi juga teman sepekerjaannya sendiri. Namun, Beauvoir (2011: 680) mengungkapkan bahwa prostitusi pada masa kerajaan juga dijadikan cara untuk menjaga kehormatan para istri. Ini berkaitan dengan tidak tersalurnya fantasi seks suami terhadap istrinya. Ia juga mengatakan bahwa selain kompetisi, para pekerja seks juga memiliki solidaritas yang kuat di antara mereka sendiri (2011: 689). Dengan solidaritas tersebut, mereka dapat mempertahankan martabatnya dalam arus masyarakat yang melawan mereka.

Pekerja seks sebagai identitas sosial bersifat kondisional. Seorang pekerja seks tidak akan menjadi pekerja seks tanpa kondisi yang memungkinkannya. Otu (2016) mengaitkan prostitusi dalam tiga karya sastra dengan faktor ekonomi dan kekuasaan. Begitupun dengan Umezurike (2015) dan Rakesh (2008) yang juga mengaitkan subjektivitas pekerja seks dengan kuasa sistem patriarkal. Dari beberapa penelitian tersebut dapat dilihat bahwa menjadi pekerja seks selalu terikat dengan kondisi. Kondisi serupa juga termanifestasi dalam tiga karya Utuy, Selamat Jalan Anak Kufur, "Menuju Kamar Durhaka", dan "Doger". Ketiganya ditulis antara tahun 1946-1956 ketika krisis kebebasan pascaproklamasi terjadi. Banyak hal yang tidak ajek. Utuy dalam karyanya pun memperlihatkan ketidakstabilan subjek dan pengakuan atas dirinya. Subjek terkadang dikenali sebagai pekerja seks, ibu, dan/ atau istri dalam tubuh yang sama sesuai kondisinya. Ruang, waktu, dan kesempatan terutama menjadi faktor yang memengaruhi pembangunan ketiga subjek tersebut.

Subjek bersifat ideologis. Althusser (2006: 84) menyatakan bahwa ideologi 
itu dibangun "oleh" subjek dan ada "untuk" subjek. Keduanya saling berkaitan sehingga tidak dapat berdiri sendiri. Dengan cara pandang seperti itulah Utuy menampilkan ketiga tokoh perempuannya. Cara Utuy mendialogkan kehidupan pekerja seks sehingga karakternya berada pada posisi subjek yang memerankan "objek" memperlihatkan sisi problematis, baik Utuy sebagai pengarang maupun para tokohnya sebagai pekerja seks. Utuy tidak menghakimi para tokohnya sebagai subjek yang salah. Ia dan para tokohnya bergumul dalam kebingungan, alih-alih kepastian. Tanpa adanya adegan erotis, Utuy menampilkan para tokohnya sebagai perempuan "terhormat". Berdasarkan hal tersebut, terlihat keraguan Utuy untuk masuk lebih dalam pada dunia prostitusi.

Prostitusi ditampilkan Utuy tidak dalam satu sisi saja. Kegagalan cintanya terhadap Onih, penjaga warung kopi yang juga bergelut dalam dunia prostitusi, membuat Utuy memiliki ambisi yang takkian selesai terhadap sosok Onih (Supartono, 2001: 154). Mungkin alasan itu pula yang mendasari Utuy tidak menuliskan adegan erotis dalam karyanya. Alih-alih menampilkan pekerja seks sebagai profesi, Utuy lebih menonjolkan pandangan mengenai pekerja seks. Titi yang kecewa pada sistem dalam dunia prostitusi, kondisi ekonomi, dan para pelanggannya (Sontani, 2014a), tokoh Aku yang kecewa pada sistem keluarga dan perubahan zaman, dan tokoh Selendang Merah yang kecewa pada suami dan tuntutan zaman yang berubah (Sontani, 2002). Dapat diargumentasikan bahwa pekerja seks dalam ketiga karya Utuy adalah sosok yang dicintai dan ditakuti, yang dalam tulisan Kristeva (1982: 1) disebut "abjek".

Dengan adanya persepsi bahwa perempuan pekerja seks adalah abjek, para tokoh pekerja seks tersebut pun dibuat berjarak dengan kehidupan "normal". Namun, Utuy tidak menghidupkan prostitusi dalam dunia yang abnormal. Sebaliknya, prostitusi seolah menjadi hal biasa dalam kehidupan. Namun, karena pekerja seks hanya didatangi sesekali, keberadaannya seolah terikat pada pelanggan. Kebahagiaan bagi pekerja seks sulit didefinisikan, bisa jadi ketika ada pelanggan atau ketika mereka tidak menjadi objek dalam prostitusi. Ahmed (2010: 2) menyampaikan hal yang menarik mengenai objek yang bahagia. Ia memaparkan bahwa kebahagiaan bukan hal yang dilekatkan pada "keinginan dan harapan", melainkan pada cara untuk mendapatkan "kebahagiaan" itu sendiri. Ini berarti kebahagiaan bukanlah hal yang didefinisikan berdasarkan kompromi diri dan orang lain, tetapi cara diri memandang kebahagiaan itu sendiri.

Beberapa tulisan mengenai Utuy dan karyanya telah dibahas dalam berbagai aspek. Tiga tulisan Aveling yang berjudul Seventeenth Century Bandanese Society in Fact and Fiction" (1967), An Analysis of Utuy Tatang Sontani's 'Suling' (1969), dan Man and Society in the Works of Indonesian Playwright Utuy Tatang Sontani, (1979) tentang karya-karya Utuy, misalnya, lebih menitikberatkan pada aspek sosiologis, baik dari pendekatan ekspresif, objektif, maupun mimetis. Ada pula tulisan yang memfokuskan pada aspek linguistik bahasa Utuy seperti skripsi Sudrajat (2012) dan Supriyanto (2007). Selain itu, masalah psikologis tokohnya juga dibahas oleh Choirunnisa (2012). Dalam tulisannya yang berjudul “Eros dan Thanatos dalam Sayang Ada Orang Lain Karya Utuy Tatang Sontani". Ia menunjukkan adanya keseimbangan insting hidup dan mati yang terepresentasi melalui tokoh-tokohnya. Namun, yang paling dekat relevansinya adalah tulisan dari Saptawuryandari (2016) yang juga membahas tokoh perempuan yang terpinggirkan dalam dua cerpen Utuy. Tulisan mengenai tokoh 
perempuan dalam karya Utuy tidak banyak dibahas. Tulisan Saptawuryandari pun tidak membahas secara spesifik mengenai profesi perempuan dalam karya Utuy. Oleh sebab itu, tulisan ini menjadi penting karena dapat memberikan perspektif baru mengenai tokoh perempuan dalam karya Utuy.

Dengan meninjau beberapa penelitian sebelumnya, dapat diargumentasikan bahwa tulisan ini bertujuan mengemukakan aspek yang berkaitan dengan perempuan dalam karya Utuy. Dengan mengacu pada perempuan, secara khusus pekerja seks, penelitian yang berjudul "Pekerja Seks dalam Tiga Karya Utuy Tatang Sontani" ini difokuskan pada (1) subjektivitas pekerja seks yang terepresentasi melalui tubuh dan ruang yang disajikan dalam teks dan (2) kaitannya dengan posisi pekerja seks sebagai subjek dan objek yang bahagia.

\section{METODE PENELITIAN}

Sumber data utama yang digunakan dalam tulisan ini adalah tiga karya Utuy, yaitu Selamat Jalan Anak Kufur, "Menuju Kamar Durhaka”, dan "Doger". Ketiga karya tersebut diterbitkan pada dekade 1950-an, yaitu pada masa produktif Utuy sebagai pengarang. Ketiga sumber data tersebut memiliki kesamaan, yaitu menceritakan kehidupan pekerja seks dari lingkungan kelas bawah. Ketiganya akan dikaji melalui pendekatan tekstual. Setiap argumen mengacu pada analisis teks secara struktural, baik melalui dialog tokoh maupun rangkaian peristiwanya. Meskipun paradigma yang digunakan berkaitan dengan kritik feminis, setiap unsur cerita dalam ketiga objek menjadi referensi utama dalam tulisan ini. Demi mendukung analisis tersebut, penulis menggunakan metode pembacaan dekat yang menurut Budianta (2006: 10) dapat membongkar "kode-kode" bahasa yang ada dalam teks. Metode ini dapat membantu proses analisis objektif terhadap karya yang dikaji dalam tulisan ini.

Meskipun begitu, Dewanto (2001: 11) mengemukakan problematika pembacaan dekat sebagai metode analisis karya sastra. Ia berargumen bahwa pembacaan dekat adalah "keniscayaan" bagi setiap pengkaji karya sastra. Oleh sebab itu, alih-alih sebagai metode, pembacaan dekat itu sendiri membutuhkan metode. Penulis memahami hal tersebut sebagai pentingnya landasan teori yang mendukung pembacaan dekat tersebut. Berdasarkan hal itu, penulis mengaitkan pembacaan terhadap teks tersebut dengan wacana subjektivitas pekerja seks yang dikemukakan oleh Beauvoir (2011) dan Estes (2008). Untuk lebih jelasnya, analisis dalam tulisan ini juga dikaitkan dengan unsur struktural karya, tokoh-tokohnya, dengan teorisasi tentang tubuh dan ruang yang diwacanakan oleh Woolf (1929) dan Young (2005). mengenai signifikansi tubuh dan ruang perempuan terhadap subjektivitasnya. \{Budianta, 2006 \#17\}

\section{HASIL DAN BAHASAN}

\section{Tubuh dan Ruang Perempuan}

Tubuh yang Interpersonal

Tubuh pertama-tama adalah personal, tetapi Booth (2016: 1) menyatakan bahwa tubuh tidak semata dibangun oleh faktor personal, melainkan juga dipengaruhi oleh aspek sosial dan kultural. Pernyataan tersebut baru mencakup tubuh secara umum, belum merambah perbedaan antara tubuh perempuan dan laki-laki. Baik tubuh perempuan maupun laki-laki, keduanya tidak lepas dari konstruksi sosiokultural. Tubuh pun, terlepas dari jenis kelaminnya, selalu bersifat interpersonal. 
Tubuh perempuan bukanlah tubuh laki-laki, tidak dapat dispesifikasikan dengan penubuhan laki-laki pula. Penubuhan perempuan dan laki-laki didasari oleh pengalaman berbeda. Tubuh familiar terhadap pengalaman masa kecil, yang bagi Straus, seperti dikutip oleh Young (2005: 28), menunjukkan adanya perbedaan mendasar antara perempuan dan laki-laki secara biologis. Berdasarkan argumen tersebut, tubuh adalah yang ditakdirkan untuk tidak dapat dipelajari. Tubuh menjadi konstruksi natural yang tidak memiliki memori dan logikanya sendiri. Young (2005: 29) menyebut klasifikasi Straus itu akan menggiring pada simpulan sederhana bahwa tubuh perempuan adalah tubuh yang tidak terdidik. Namun, jika dilihat dari sudut pandang berbeda, tubuh perempuan justru dapat dikatakan sebagai tubuh yang adaptif. Ia (tubuh perempuan) memiliki kemampuan untuk bertahan dalam dunia yang "memosisikannya" sebagai tubuh yang lemah.

Masih merujuk pada argumen Straus sebelumnya, yang secara paradoks justru menyatakan bahwa tubuh perempuan adalah tubuh yang adaptif, Utuy pun menampilkan pekerja seks secara paradoks. Utuy dan pekerja seks menikmati hiburan yang tidak menghibur. Saya sebagai pembaca tidak lantas dibuat bahagia setelah membaca karya-karya Utuy dan mungkin Utuy pun tidak bertujuan begitu. Utuy dengan konsisten menggambarkan pekerja seks dalam tubuh berparas cantik. Dengan begitu, tubuh pekerja seks tersebut dapat dipahami sebagai aset. Tokoh yang diasosiasikan sebagai Selendang Merah dalam "Doger", misalnya, berparas cantik dengan tubuh berisi, "... badannya besar, parasnya ter-cantik di antara semua." (Sontani, 2002: 28-29), yang sangat mendukung pekerjaanya sebagai penari doger yang harus menarik penonton dengan gerakan tubuhnya. Tubuh dalam konteks tersebut ditampilkan sebagai aset hiburan yang mendatangkan keuntungan finansial Hiburan dengan kata kerja aktif "menghibur" memiliki makna yang ambivalen. Menghibur untuk sekadar membagikan kebahagiaan berbeda dengan "menghibur" dalam konteks memberikan kenikmatan. Tubuh sebagai aset hiburan dalam dunia prostitusi pun mengacu pada makna kedua. Namun, Utuy tidak mempersempit makna "menghibur" menjadi kesekadaran. Dalam kasus tokoh Titi, "menghibur" juga diartikan oleh pelanggannya dalam makna sebenarnya, “... Dia sekarang ada di dalam keadaan luka hati, sebab kekasihnya yang serupa dengan kau itu kawin dengan orang lain." (Sontani, 2014a: 18). Titi dijadikan semacam "obat" yang dibeli di apotek. Hal tersebut memosisikannya sebagai objek yang siap "ditelan". Namun, Ia menolak objektifikasi tersebut setelah ruangnya (kamar) dijadikan tempat pasif pertunjukannya atas pelanggan tersebut,

"Laki-laki gila," jawabnya. "Setelah masuk ke kamar, dia tidak berbuat apa-apa selain duduk terdiam kaya tihul. Diajak tidur menggéléngkan kepala. Setelah lama terdiam, tiba-tiba dia berair mata. Dan setelah ditanya apa sebabnya bukan dia menyahut, tapi jatuh terguling kaya orang sekalor" (Sontani, 2014a: 23).

Ketidakberterimaan Titi mengenai pandangan pelanggan atas tubuhnya sebagai aset pasif menunjukkan subjektivitas dirinya sebagai pekerja seks. Meskipun Estes (2008: 354) berpandangan bahwa uang adalah motivasi utama untuk dipertukarkan dengan "sandiwara seks" tanpa hasrat seksual, pekerja seks dalam Selaman Jalan Anak Kufur dan "Doger" menolak transaksi pasif. Pekerja seks 
melakukan tindakan teatrikal, bukan pameran lukisan tubuh. Hanya dengan jalan itulah subjektivitas pekerja seks dalam keruangannya dapat tetap dipertahankan.

Tubuh sebagai aset/modal bagi pekerja seks juga ditampilkan dalam "Doger". Tokoh utama, Selendang Merah, dalam "Doger" adalah tokoh yang memiliki tubuh yang paling ideal bagi seorang penari doger. Tubuhnya tidak terlalu kurus, tetapi juga tidak terlalu gemuk seperti yang diteriakkan oleh anak kecil dalam "Doger", "Dia! Dialah yang paling besar pantatnya!” (Sontani, 2002: 59). Tubuh Selendang Merah tersebut menjadi tubuh ideal yang terobjektifikasi melalui mata para penonton. Dengan tubuhnya tersebut ia menjadi penari paling tenar yang diperebutkan para penonton laki-lakinya. Meskipun begitu, ia menari; tubuhnya bukan objek pasif. Alih-alih objek, ia bahkan adalah subjek yang mengatur arah pandang penontonnya.

Hal menarik lainnya dari cerita Si Selendang Merah juga adalah kalimat Utuy dalam cerpen tersebut, "... Sedang mata kenyang pula memandang gerak-gerik si Selendang Merah yang menembak-nembakkan mata kepada tiap laki-laki yang mengasi senyum minta perhatian" (Sontani, 2002: 59). Kutipan tersebut sangat menarik. Utuy menampilkan lebih dari satu perspektif dalam satu adegan. Ia membiarkan para penonton "memandang" Selendang Merah sebagai objek aktif, tetapi ia juga menjadikan Selendang Merah sebagai subjek yang "menembak-nembakkan mata"nya. Ia pun "menembak-nembakkan mata" pada para penonton yang "minta perhatian". Posisi tokoh Selendang Merah pada oposisi subjek-objek dalam adegan tersebut menjadi subjek dan objek. Ia sebagai penari membiarkan tubuhnya sebagai objek yang dipandang. Namun, aksi tokoh Selendang Merah tersebut juga dapat dipandang sebagai aksi mempermainkan mata penonton. Ia sedang berpura-pura menjadi objek.

Selain sebagai aset, pekerja seks juga ditampilkan sebagai entitas yang bertubuh eksotis dan eksklusif. Mereka mempunyai wilayah tersendiri yang berjarak dari kehidupan berkeluarga, misalnya Gang M. dalam “Menuju Kamar Durhaka”, tempat suami tokoh $\mathrm{Aku}$ "... hampir setiap malam meninggalkan rumah, pergi ke tempat perempuan lacur di Gang M." (Sontani, 2002: 15). Meskipun dibedakan dalam ketiga cerita, tetapi selalu ada tempat khusus bagi para pekerja seks dan pelanggannya untuk bertemu dalam karya-karya Utuy. Eksklusivitas tersebut dapat "menabukan" dan juga "ditabukan" tubuh pekerja seks. Tubuh pekerja seks pun menjadi eksotis; ambivalen antara tubuh yang dirindukan dan dihinakan. Ia juga dapat merusak keluarga seperti dalam "Menuju Kamar Durhaka" atau dirusak oleh keluarga seperti dalam "Doger". Tubuh pekerja seks menjadi aset yang ambigu, tidak pernah ajek, dan tidak pernah selesai.

Tubuh eksotis para tokoh perempuan pekerja seks dalam tiga karya Utuy terutama dieksklusifkan melalui uang. Uang dengan segala transaksi yang menawarkan pertukaran bersifat mewah. Tubuh pekerja seks tidak gratis; tidak dapat dinikmati oleh setiap orang. Tokoh Titi dalam Selamat Jalan Anak Kufur menolak "ngamar" dengan pembayaran ditangguhkan (Sontani, 2014a), sedangkan tokoh Aku dalam "Menuju Kamar Durhaka" memimpikan kehidupan yang lebih mapan secara finansial dengan menjadi pekerja seks (Sontani, 2002). Begitupun dengan si Selendang Merah. Ketiga pekerja seks tersebut adalah pemberi pengalaman mewah. Namun, mereka serupa berlian dalam kubangan; dijauhkan dari kehidupan rumah tangga karena kemewahannya dapat menimbulkan petaka. Padahal, Utuy dalam 
"Menuju Kamar Durhaka" juga menampilkan kehidupan rumah tangga sebagai pelacuran terstruktur. Mengenai pernikahan sebagai "prostitusi berkontrak" juga telah dipaparkan oleh Beauvoir (2011: 680) dalam bukunya, The Second Sex.

\section{Ruang Penghibur yang Marginal}

Ruang perempuan bagi Woolf (1929: 4), berada dalam konteks dirinya sebagai penulis, menekankan pentingnya uang dan ruang bagi perempuan untuk menulisuntuk menjadi agen. Argumen tersebut dapat diposisikan dalam konteks pekerja seks dalam karya Utuy, bahwa pekerja seks membutuhkan uang dan ruang aktif (kamar) untuk menjadi subjek. Hanya dengan uang, tanpa ruang untuk mengaktualisasikan diri, pekerja seks dapat kehilangan kendalinya atas pelanggan. Bahkan, dalam karya-karya Utuy, uang terkadang dikalahkan oleh ruang. Pentingnya ruang dalam subjektivitas pekerja seks menandakan bahwa Utuy, sebagai penulis laki-laki, tidak hanya menciptakan karakter perempuan, tetapi memberinya tempat dan kesempatan untuk menjadi subjek yang aktif. Namun, prostitusi pada tiga karya Utuy - dalam kerangka patriarkal - tetap diposisikan sebagai tempat yang "didatangi" oleh lakilaki yang mengembara mencari perempuan "penghibur". Jadi, sulit menghapuskan citra perempuan yang tertutup dalam ruang yang sempit.

Pekerja seks dalam tiga karya Utuy mempunyai ruangnya secara spesifik, Titi dengan kamar kecilnya, Aku dan Netty dengan kamar "durhaka"-nya di Gang M., dan Selendang Merah dengan "arena-di-bawah-suluh" sebagai panggungnya untuk menari. Pemberian ruang sempit tersebut bertolak belakang dengan penggambaran Utuy terhadap tokoh-tokohnya. Kesan merendahkan profesi pekerja seks kelas bawah melalui ruang tersebut menunjukkan bahwa pekerja seks adalah profesi yang sulit berterima dalam masyarakat cerita. Pekerja seksnya ditampilkan baikbaik saja, tetapi ruang untuk mereka sangat terbatas dan kotor. Bukankah ini dapat dimaknai sebagai ketiadaan ruang yang pantas? Dalam "Doger", misalnya, terdapat kutipan, "... Si Baju Kaos menarik-narik tangan si Selendang Merah, terus pergi bersama-sama, keluar dari gelanggang, berjalan menuju ke tempat gelap." (Sontani, 2002: 62), yang menunjukkan bahwa ruang subjektivitas pekerja seks berada di tempat tersembunyi. Utuy menabukan ruang bagi pekerja seks yang posisinya juga dijadikan penabu dalam konteks cerita.

Tokoh Aku dalam Menuju Kamar Durhaka, misalnya, keluar dari ranah domestik keluarganya setelah rumah tangganya berantakan karena pekerja seks. Ia memilih untuk masuk ke "kamar durhaka" demi melampiaskan amarahnya. Hal tersebut berkebalikan dengan Netty yang keluar dari dunia prostitusi untuk membangun sebuah keluarga. Kedua kondisi dalam satu cerita tersebut menegaskan bahwa Utuy tidak menilai keputusan perempuan berdasarkan benar atau salah. Ia mempertukarkan posisi dan identitas mereka dengan pandangan bahwa ruang domestik dan "kamar durhaka" berada dalam satu tingkatan. Kedua ruang mengekang dengan caranya sendiri. Tidak ada subjek yang bebas sepenuhnya, Titi pun dikerangkeng oleh aturan bahwa,

“... cabol itu bukan babu cuci yang membutuhkan laki-laki. Cabol adalah cabol. Dan cabol itu tidak lebih dan tidak kurang dari perempuan séwaan. Dan sekali kau jadi cabol, pendirian itu mesti kaujadikan pegangan. Lepas dari pegangan itu, kau jadi orang kufur" (Sontani, 2014a: 15). 
Pada kutipan tersebut, ruang bagi pekerja seks pun diberlakukan sama dengan aturan dan syarat sehingga tidak ada bedanya antara ruang pekerja seks, istri, dan ibu. Tokoh Aku dalam Menuju Kamar Durhaka, misalnya, tetap perlu membereskan rumah, menata perabotan, dan mengurus suaminya untuk membuat rumah seolah menjadi ruang dirinya. Dalam kasus ini, baik pekerja seks maupun istri, memiliki kesamaan kondisi, yaitu dikerangkeng ruang terbatas yang mengatur pergerakannya.

Identitas pekerja seks, istri, dan ibu boleh berbeda. Cara dan kesempatan mereka bekerja pun berbeda, tetapi ruang yang diberikan tetap sama: kumuh, kecil, tersembunyi. Saya berargumen bahwa hal tersebut mengindikasikan adanya persepsi ketertutupan ruang perempuan. Seperti halnya diutarakan Young berdasarkan tulisan Merleau-Ponty (2005: 39), bahwa ruang perempuan untuk membangun eksistensinya cenderung tertutup dan terbatas. Ketertutupan dan keterbatasan tersebut berkaitan dengan penubuhan perempuan. Tubuh dan ruang perempuan seperti sudah ditakdirkan berpasangan, tidak terpisahkan, sehingga tubuh pekerja seks pun tidak dapat dikatakan sebagai tubuh yang bebas. Utuy memperlihatkan kompleksitas tubuh dan subjektivitas pekerja seks sebagai masalah yang tidak pernah selesai. Masalah dualitas ruang perempuan, terutama, ditampilkan sebagai ilusi dalam kedok identitasnya sebagai pekerja seks.

\section{Posisi Pekerja Seks: Subjek dan Objek yang Bahagia}

Apakah menjadi subjek berarti juga menjadi bahagia? Jika kebahagiaan dapat dicapai dengan menjadi subjek, maka subjektivitas juga dapat diartikan sebagai proses untuk menjadi bahagia. Namun, dapat diargumentasikan bahwa kebahagiaan tidak pernah sederhana justru karena kesederhanaannya. Subjek dan kebahagiaan mungkin takpernah berkorelasi secara penuh. Althusser (2006: 85) berargumen bahwa setiap manusia telah secara otomatis menjadi subjek ketika dilekati ideologi. Namun, hal tersebut mengandung paradoks. Althusser pun menyatakan bahwa baik ideologi maupun subjek tidak dapat hidup terpisah. Ideologi tidak akan pernah ada tanpa subjek, begitupun subjek. Hal tersebut sekaligus mengukuhkan subjek menjadi/sebagai objek. Jadi, jika menjadi subjek adalah kebahagiaan, maka secara otomatis menjadi objek pun adalah kebahagiaan. Posisi subjek-objek pun menjadi tidak berkorelasi penuh dengan kebahagiaan.

Pembahasan mengenai kebahagiaan telah diargumentasikan oleh Ahmed (2010: 21), bahwa kebahagiaan yang dicantolkan pada hal material telah menuntun manusia pada perannya sebagai objek. Hal tersebut berkaitan dengan cara manusia "dibuat" bahagia oleh sesuatu. Manusia dalam kerangka pemikiran Ahmed tidak lagi dipandang sebagai subjek secara otomatis. Namun, bukan berarti pula bahwa subjek selalu tidak bahagia. Permasalahan ini muncul karena definisi kebahagiaan dipertukarkan dengan kenikmatan atau kenyamanan. Kenikmatan dan kenyamanan menuntut faktor materialistis yang lebih konkret, sedangkan bahagia sering tidak jelas batasannya. Antara subjek-objek atau bahagia-tidak bahagia, keduanya dapat mempersempit ruang diskusi. Begitupun bagi para tokoh perempuan dalam tiga karya Utuy. Ketiganya - Titi, Selendang Merah, dan Aku - memilih untuk "terjebak" sebagai pekerja seks. Pilihan ini menjadi samar, bukan lagi sekadar tentang kebahagiaan, kenikmatan, dan kepuasan. 
Beauvoir (2011: 692) menyatakan bahwa prostitusi adalah pekerjaan yang menekan perempuan secara seksual dan ekonomi. Sama halnya dengan pernikahan yang membatasi perempuan secara seksual dan ekonomi. Namun, pekerja seks mengalami tekanan yang lebih kuat dari masyarakat. Beauvoir (2011: 681) mengasosiasikannya dengan "perbudakan". Meskipun begitu, ia menyangkal bahwa perempuan menggunakan tubuhnya semata-mata sebagai instrumen. Sebaliknya, perempuan dapat menjadikan pelanggannya sebagai instrumen untuk memenuhi kebutuhannya. Namun, kembali pada pernyataan Ahmed sebelumnya, menggantungkan kebahagiaan pada sesuatu di luar dirinya dapat menjadikan seseorang itu objek. Jadi, terutama untuk menjadi objek yang bahagia, ia perlu menjadi subjek yang bahagia dulu, yang melakukan sesuatu dengan bahagia.

Pada akhirnya, perputaran posisi dalam konsep kebahagiaan menjadi sangat membingungkan. Tokoh Titi dalam Selamat Jalan Anak Kufur lebih memilih pergi dengan Rais, tukang becak yang menyukainya, dibandingkan tetap bertahan dengan pekerjaannya sebagai pekerja seks. Titi dalam hal ini berada dalam posisi subjek dan objek. Ia memilih untuk bahagia atau ia hanya memilih ketidakpastian sambil berharap kebahagiaan. Secara ekonomi, ia tidak akan bahagia hidup dengan Rais, tetapi ia dimanusiakan oleh Rais. Namun, ambivalensi itu terus menghantui pilihan Titi. Dalam konsep Ahmed, pilihan Titi tersebut dapat tidak menjadi kebahagiaan ketika kebahagiaan tersebut dicantolkan pada entitas di luar dirinya.

Titi pun mengatakan kebimbangannya dalam kalimat terakhir yang diucapkannya, “... aku tidak tahu. Tadi aku masih bisa memilih. Tapi sekarang aku jadi capé" (Sontani, 2014a: 41). Kutipan tersebut memperlihatkan betapa kebahagiaan menjadi sangat membingungkan. Kebahagiaan bagi Titi menjadi tidak sederhana. Awalnya, menjadi pekerja seks adalah hal yang "menggembirakan" secara material, "Malam itu bukan malam yang menggembirakan. Biasa-biasa ramai, di tempat penjualan sirop...." (Sontani, 2014a: 11). Lalu, Titi ingin dipuaskan dengan cara yang lain, "Itu kalau dia cukup memberikan kepuasan dalam memelesirkan" (Sontani, 2014a: 40). Namun, seperti pada kutipan pertama, Titi akhirnya kebingungan karena ia tidak yakin dengan pilihannya. Kebahagiaan Titi pun menjadi berubah-ubah karena ia menggantungkannya pada kebendaan.

Titi, sama seperti tokoh Selendang merah, ditampilkan sebagai pekerja seks yang awalnya didorong oleh faktor ekonomi, sedangkan tokoh Aku didorong oleh kecemburuannya terhadap Netty-pekerja seks yang merebut suaminya. Ketiganya didorong oleh faktor luar yang bagi Ahmed tidak dapat dijadikan faktor kebahagiaan. Namun, faktor luar tersebut pun bukan berarti tidak dapat dijadikan landasan kebahagiaan karena, sebagaimana dikutip oleh Ahmed dari Mihály Csíkszentmihályi (2010: 22), kebahagiaan bergantung pada cara manusia "menginterpretasikan" kebahagiaan itu sendiri. Untuk itu, dalam posisinya sebagai objek pun, manusia tetap dapat bahagia. Namun, apa yang mendasari manusia untuk dapat bahagia tanpa dapat diukur? Padahal, manusia tidak dapat bahagia hanya dengan "memikirkannya" saja karena pikiran dan tubuh adalah sesuatu yang berkelindan.

Persoalan pun kembali pada masalah tubuh dan keruangan. Kebahagiaan tidak akan pernah didapatkan tanpa adanya tubuh dan ruang bagi perempuan, pekerja seks secara spesifik. Dalam tiga karya Utuy, tubuh dan ruang bagi pekerja seks ditampilkan sebagai aset sedemikian sehingga menjadi faktor primer bagi 
subjektivitas mereka. Faktor penting lainnya adalah cara para pekerja seks tersebut menginterpretasikan kondisi mereka. Tokoh Aku dalam Menuju Kamar Durhaka adalah tokoh yang mengartikan kehidupan pernikahannya sebagai penjara yang membatasi setiap haknya. Ia memilih menjadi pekerja seks untuk membebaskan dirinya dari belenggu pernikahan, yang bagi Beauvoir (2011: 680) memiliki kesamaan dengan prostitusi. Sama halnya dengan Titi, pada akhirnya tokoh Aku pun berlabuh pada kebingungan, "... Dan sudah sebaiknya pula, jika aku tadi pulang ke rumah orangtuaku, ke tempat orang-orang yang sepaham dengan daku, tidak mesti datang ke tempat sarang setan ini" (Sontani, 2002: 41). Namun, tokoh Aku tetap dapat istirahat dengan nyaman "... di atas kasur yang terasa empuk ... di atas bantal yang terasa sejuk menyejukkan pikiran." (Sontani, 2002: 41). Kedua kutipan tersebut memperlihatkan ambivalensi tokoh utama.

Meskipun begitu, ketiga tokoh dalam karya Utuy adalah pelaku. Dalam kebingungannya tentang kebahagiaan dan masa depannya, mereka tetap menjalani kehidupannya sebagai manusia yang berhak memilih. Meskipun ruang yang mereka miliki adalah kamar sempit yang kumuh, pusat utama dalam kamar tersebut tetaplah diri mereka sebagai perempuan, pekerja seks. Berbeda dengan tokoh dalam Selamat Jalan Anak Kufur dan Menuju Kamar Durhaka, "Doger" menampilkan ruang yang lebih terbuka bagi tokoh Selendang Merah. Namun, dari semua tokoh, Selendang Merahlah yang paling memiliki "nama", tetapi secara bersamaan tak bernama. Ia menjadi subjek utama yang "membahagiakan" penonton sambil memperdayai mereka dengan berpura-pura menjadi objek. Berikut adalah tabel yang memperlihatkan persamaan dan perbedaan ketiga tokoh dalam karya Utuy.

Tabel 1. Subjektivitas Ketiga Tokoh

\begin{tabular}{|c|c|c|c|c|}
\hline \multirow{2}{*}{ Tokoh } & \multirow{2}{*}{ Faktor } & \multicolumn{2}{|c|}{ Subjektivitas } & \multirow{2}{*}{ Akhir } \\
\hline & & Tubuh & Ruang & \\
\hline $\begin{array}{l}\text { Titi dalam } \\
\text { Selamat Jalan } \\
\text { Anak Kufur }\end{array}$ & Ekonomi & Cantik & $\begin{array}{l}\text { Kamar kecil } \\
\text { dan jauh dari } \\
\text { keramaian }\end{array}$ & $\begin{array}{l}\text { Meninggalkan } \\
\text { pekerjaannya } \\
\text { untuk berpelesir }\end{array}$ \\
\hline $\begin{array}{l}\text { Aku dalam } \\
\text { Menuju Kamar } \\
\text { Durhaka }\end{array}$ & $\begin{array}{l}\text { Kecemburuan, } \\
\text { keterkekangan }\end{array}$ & $\begin{array}{l}\text { Cantik tetapi } \\
\text { tidak pandai } \\
\text { berdandan }\end{array}$ & $\begin{array}{l}\text { Kamar kecil, } \\
\text { kotor, dan berada } \\
\text { di jalan sempit }\end{array}$ & $\begin{array}{l}\text { Mengistirahatkan } \\
\text { tubuhnya di } \\
\text { kamar sebelum } \\
\text { pulang kampung }\end{array}$ \\
\hline $\begin{array}{l}\text { Selendang } \\
\text { Merah dalam } \\
\text { "Doger" }\end{array}$ & Ekonomi & $\begin{array}{l}\text { Cantik dan } \\
\text { badan besar }\end{array}$ & $\begin{array}{l}\text { Di dalam } \\
\text { lingkaran sebagai } \\
\text { panggung dan di } \\
\text { "belakang" yang } \\
\text { gelap }\end{array}$ & $\begin{array}{l}\text { Tidak jelas } \\
\text { akhirnya. }\end{array}$ \\
\hline
\end{tabular}

Sumber: ketiga karya Utuy

Dari tabel nomor 1 tersebut, dapat dibaca bahwa faktor pendorong ketiga tokoh tersebut untuk menjadi pekerja seks adalah faktor ekonomi dan/atau kecemburuan. Faktor material dan situasional tersebut, menurut Ahmed (2010: 22), sering diasosiasikan dengan penyebab kebahagiaan. Itu berarti kebahagiaan secara sosial dikaitkan dengan objek di luar dirinya. Pola pikir tersebut menempatkan kebahagiaan sebagai sesuatu yang temporal atau bahkan ilusi. Selain itu, hal tersebut 
juga terus-menerus menuntut elemen baru di luar dirinya yang menandakan bahwa dirinya tidak pernah cukup untuk dijadikan subjek yang berbahagia. Dengan memenuhi faktor yang "tidak cukup" dari dirinya, ketiga tokoh dalam karya Utuy pun terus mencari kenikmatan, kepuasan, dan kenyamanan. Aset yang dapat membantu mencapai hal tersebut adalah tubuh mereka. Ketiganya ditampilkan sebagai perempuan cantik atau yang pernah cantik-masalah cantik pun akan menjadi sangat panjang untuk diperdebatkan. Melalui "kecantikan" yang diacu oleh Utuy, mereka secara otomatis menjadi aset, objek. Pilihan mereka untuk menggunakan aset tersebutlah yang menuntun mereka menjadi subjek. Sebagai modal pendukung, mereka mendirikan/didirikan oleh ruang.

Akhir cerita ketiga tokoh tersebut, seperti tertera dalam tabel 1, adalah yang paling krusial. Hal tersebut menggiring penulis pada sebuah simpulan yang pada hakikatnya memperlihatkan pandangan Utuy terhadap pekerja seks. Ada tiga akhir yang jika diurutkan, maka menjadi: (1) dilakukan, (2) dipikirkan/diwacanakan, dan (3) dibiarkan begitu saja. Pertama, tokoh Titi dalam Selamat Jalan Anak Kufur mengambil sikap yang tegas untuk meninggalkan pekerjaannya meski dalam kondisi bingung. Kedua, tokoh Aku mewacanakan untuk pulang ke kampung halamannya setelah matahari terbit, tapi belum benar-benar direalisasikan. Ketiga, tokoh Selendang Merah membicarakan perihal pekerjaannya dengan suaminya, tetapi tidak memperlihatkan adanya niatan untuk meninggalkan pekerjaannya. Dari ketiga akhir tersebut, dapat diargumentasikan bahwa semua tokoh berakhir dalam kebimbangan dan kerentanan. Tidak diperlihatkan adanya penghakiman perihal kebenaran dan kebaikan. Perihal mereka adalah subjek atau objek yang bahagia menjadi tidak dapat ditegaskan. Utuy pun membiarkan ketiga tokohnya untuk terus terombang-ambing dalam proses yang takpernah usai.

\section{SIMPULAN}

Perempuan sebagai pekerja seks dalam tiga karya Utuy, yaitu Selamat Jalan Anak Kufur, "Menuju Kamar Durhaka”, dan "Doger" ditampilkan melalui tokoh Titi, Aku, dan Selendang Merah. Ketiga tokoh utama perempuan tersebut ditampilkan sebagai pekerja seks yang menolak dijadikan objek seksual semata. Ketiganya menyuarakan problematika pekerja seks kelas bawah yang bersandiwara tunduk dalam fantasi laki-laki. Resistensi tersebut ditampilkan melalui tubuh dan ruang perempuan sebagai pekerja seks. Pertama, tubuh pekerja seks ditampilkan sebagai aset yang ambivalen dalam posisinya sebagai subjek dan objek. Kedua, ruang pekerja seks ditampilkan eksklusif, rangkap, dan marginal. Dapat dimaknai bahwa: (1) tubuh dan ruang pekerja seks adalah alat untuk melawan kuasa pelanggannya. Jadi, kesadaran bahwa tubuh dan ruangnya adalah objek dimanfaatkan oleh pekerja seks untuk mendapatkan keinginannya: uang dan pengakuan. Berdasarkan perspektif pekerja seks tersebut, (2) dapat dikatakan bahwa cara pekerja seks memanfaatkan tubuh dan ruangnya adalah bentuk usaha mereka untuk menjadi subjek. Perspektif tokoh lain yang mengobjektifikasi dirinya menjadi tidak penting. Oleh karena itu, posisi subjek-objek pun menjadi sangat subjektif. Baik itu menjadi subjek maupun objek, pekerja seks dalam ketiga karya Utuy, terus mencari makna kebahagiaan dalam hidupnya. Oleh sebab itu, dapat disimpulkan bahwa pekerja seks dalam tiga karya Utuy ditampilkan sebagai pekerja seks yang terus berproses mempertahankan subjektivitasnya. 


\section{DAFTAR PUSTAKA}

Ahmed, S. (2010). "Happy Objects" dalam The Promise of Happiness (hlm. 21-49). Durham \& London: Duke University Press.

Althusser, L. (2006). "Ideology and Ideological State Apparatus (Notes towards an investigation)". Dalam M. G. D. D. M. Kellner (Ed.), Media and Cultural Studies: KeyWorks (hlm. 79-87). Victoria Australia: Blackwell Publishing.

Aveling, H. G. (1967). "Seventeenth Century Bandanese Society in Fact and Fiction: 'Tambera' Assessed". Bijdragen Tot De Taal-, Land-En Volkenkunde, 123 (3), hlm. 347-365.

. (1969). "An Analysis of Utuy Tatang Sontani's 'Suling'”. Journal of the Humanities and Social Sciences of Southeast Asia and Oceania, 125 (3), hlm. 328-343. doi: http;/ / dx.doi.org/10.1163/22134379-90002837

. (1979). Man and Society in the Works of the Indonesian Playwright Utuy Tatang Sontani. Hawaii: Southeast Asian Studies Program, University of Hawaii.

Beauvoir, S. d. (2011). "Prostitutes and Hetaeras" (C. Borde \& S. Malovany-Chevallier, Terj.) The Second Sex (hlm. 680-701). New York: Vintage Books.

Booth, Kelvin J. (2016). "The Meaning of the Social Body: Bringing George Herbert Mead to Mark Johnson's Theory of Embodied Mind". William James Studies, 12 (1), hlm. 1-18.

Choirunnisa. (2012). "Eros dan Thanatos dalam Sayang Ada Orang Lain Karya Utuy Tatang Sontani”. (S1), Universitas Padjadjaran.

Budianta, M. (2006). “Budaya, Sejarah, dan Pasar: New Historicism dalam Perkembangan Kritik Sastra”. Susastra, Jurnal Ilmu Sastra dan Budaya, 2 (3), hlm. 1-19.

Dewanto, N. "Pembacaan Dekat atau Jauh? Melintasi Sastra dan Seni Rupa". Kalam (22), hlm. 11-32.

Estes, Y. (2008). "Prostitution: A Subjective Position". Dalam A. Soble \& N. Power (Eds.), The Philosophy of Sex: Contemporary Readings (hlm. 353-366). Lanham, MD: Rowman \& Littlefield.

Kristeva, J. (1982). Powers of Horror: An Essay on Abjection (L. S. Roudiez, Trans.). New York: Columbia University Press.

Nopianti, R. (2014). “Dari Ronggeng Gunung ke Ronggeng Kaler: Perubahan Nilai dan Fungsi". Patanjala, 6 (1), hlm. 81-92.

Otu, O. O. (2016). "Prostitution: The Economic of Sex and Power Dynamics in El Sadawi's Woman at Point Zero, Adimora Ezeigbo's Trafficked, and Unigwe's Black Sisters Street". World Journal of English Language, 6 (4), hlm. 8-15. 
Rakesh, S. (2008). “Desire, Sex and Subjectivity: You've Got Eleven Minutes to Live!" Hispanet Journal, 1, hlm. 1-23.

Rosidi, A. (2018). Ikhtisar Sejarah Sastera Indonesia. Bandung: PT Dunia Pustaka Jaya.

Saptawuryandari, N. (2016). "Perempuan yang Termarginalkan dalam Cerpen "Menuju Kamar Durhaka" dan "Berita dari Parlemen" Karya Utuy Tatang Sontani". Aksara, 28 (1), hlm. 39-48. doi: http:/ / dx.doi.org/10.29255/aksara. v28i1.15.39-48

Sontani, U. T. (2002). Menuju Kamar Durhaka. Jakarta: PT Dunia Pustaka Jaya. . (2014a). Selamat Jalan Anak Kufur. Bandung: PT Dunia Pustaka Jaya. . (2014b). "Sepatah Kata" dalam Awal dan Mira. Bandung: PT Dunia Pustaka Jaya.

Sudrajat, N. H. R. (2012). "Pemanfaatan Konsep "Muka” ("Face”) dalam Dialog Awal dan Mira Karya Utuy Tatang Sontani: Analisis Pragmatik". (S1), Universitas Padjadjaran.

Supartono, A. (2001). “Rajawali Tak Bisa Pulang: Karya-karya Eksil Utuy Tatang Sontani”. Kalam (18), hlm. 133-159.

Supriyanto. (2007). “Struktur dan Tekstur Drama “Sayang Ada Orang Lain” Karya Utuy Tatang Sontani dan Implementasinya dalam Pembelajaran Sastra di SMA". (S1), Universitas Sanata Dharma. Diakses melalui http://repository. usd.ac.id/id/eprint/20765

Tallent, A. (2005). “Listening to the Prostitute's Body: Subjectivity and Subversion in the Erotic Memoir Novels of Eighteenth-Century France". Proceedings of the Western Society for French History, 33, hlm. 211-233.

Umezurike, U. P. (2015). “Sexuality and Subjectivity in Chika Unigwe's On Black Sisters' Street". Unizik Journal of Arts and Humanities, 16 (1), hlm. 1-25.

Woolf, V. (1929). A Room of One's Own: Feedbooks.

Young, I. M. (2005). “Throwing Like a Girl: A Phenomenology of Feminine Body Comportment, Motility, and Spatiality" dalam On Female Body Experience (hlm. 27-45). Oxford, New York, dll: Oxford University Press. 